\title{
Reel Kesim Güven Endeksi ile Borsa İstanbul Sektör Endeksleri Arasındaki İlişkinin Test Edilmesi ${ }^{1}$
}

\author{
Sinem Eyüboğlu ${ }^{\mathrm{a}}$
}

\author{
Kemal Eyüboğlu ${ }^{b}$
}

\begin{abstract}
Öz: Son yıllarda yapılan çalışmalarda yatrımcıların yatırım kararı alırken psikolojik faktörlerden etkilendiği belirlenmiştir. Yatırımcıların ekonomiye ilişkin beklentilerini öğrenebilmek için güven endekslerinden yararlanılmaktadır. Bu çalışmada Borsa istanbul sektör endeks getirileri ile Reel Kesim Güven Endeksi arasındaki kısa ve uzun dönemli ilişkilerin olup olmadığı araştııımıştr. Farkı seviyede durağan oldukları belirlenen borsa endeksleri ile reel kesim güven endeksi arasındaki kısa ve uzun dönemli ilişkiler ARDL Sınır Testi ile araştııılmıştr. Elde edilen bulgular reel kesim güven endeksi ile tüm sektör endeksleri arasında hem uzun dönemde hem de kısa dönemde ilişki olduğunu ortaya koymuştur. Ayrıca kısa dönemde reel kesim güven endeksindeki artşıı borsa endeks getirilerini (XULAS ve XTAST hariç) pozitif yönde etkilediği belirlenmiştir. Nedensellik sonuçları ise çoğunlukla sektör endekslerinden reel kesim güven endeksine doğru bir nedensellik ilişkisinin olduğunu göstermiștir. Böylece psikolojik faktörlerin hisse senedi piyasasındaki değişimlerin belirleyicisi olarak dikkate alınması gerektiği ortaya konulmuştur.
\end{abstract}

Anahtar Sözcükler: Reel Kesim Güven Endeksi, Borsa Istanbul, Sınır Testi, Toda-Yamamoto Nedensellik Testi

JEL Sınıflandırması: D53, E44, M21

\section{Testing the Relationship between Real Sector Confidence Index and Borsa Istanbul Sector Indices}

\begin{abstract}
In recent years, it has been determined that investors are influenced by psychological factors while making investment decisions. Confidence indices are used to learn investors' expectations about the economy. In this paper, it is investigated whether there is short and long-run relationship between Borsa Istanbul sector indices and real sector confidence index. The short and long-run relationships between the stock indices and the real sector confidence index, which are determined to be stationary at different levels, are tested by ARDL Bound Test. The findings show that there is a relationship between the real sector confidence index and all sector indices both in the long-run and in the short-run. In addition, it is determined that the increase in real sector confidence index affects positively stock returns (except XULAS and XTAST) in the short-run. The results of causality showed that mostly there is a causality relationship from sector indices to real sector confidence index. Thus, it has been shown that psychological factors should be considered as determinants of changes in the stock market.
\end{abstract}

Keywords: Real Sector Confidence Index, Borsa Istanbul, Bound Test, Toda-Yamamoto Causality Test

JEL Classification: D53, E44, M21

\footnotetext{
aPhD., Karadeniz Technical University, Faculty of Economic and Administrative Sciences, Department of Econometrics, Trabzon, Turkiye, sinemyilmaz17@hotmail.com (ORCID ID: 0000-0002-3525-9173)

bPhD., Karadeniz Technical University, Faculty of Economic and Administrative Sciences, Department of Business Administration, Trabzon, Turkiye, keyuboglu@msn.com (ORCID ID: 0000-0002-2108-9732)
} 


\section{Giriş}

Etkin Piyasalar Hipotezinin aksine davranışsal finans alanında yapılan çalışmalar yatırımcıların rasyonel olmadığını ve yatırım kararı alırken psikolojik faktörlerden etkilendiğini ortaya koymuştur. Dolayısıyla varlık fiyatlarının psikolojik faktörlere göre şekillendiği söylenebilir. Bu faktörlerin başında yatırımcıların ülkenin makroekonomik görünümüne ilişkin beklentileri gelmektedir.

Bireylerin geleceğe yönelik beklentilerinin iyimser ya da kötümser olması farklı ekonomik sonuçlar ortaya çıkarmaktadır. İyimser beklenti, bireyleri daha çok harcamaya teşvik ederken, kötümser beklenti ise harcamaların kısımasını ve daha fazla ihtiyatlı olmayı zorunlu kılmaktadır. Bu durum reel sektördeki firmaların finansal performanslarını etkileyecektir. Dolayısıyla beklentilerinin düzenli olarak izlenmesi piyasa katılımcılarına önemli veriler sağlayacaktır (Olgaç ve Temizel, 2008: 226). Yatırımcıların ekonomiye ilişkin görüşlerini ve gelecek ile ilgili beklentilerini öğrenebilmek için ise güven endekslerinden yararlanılmaktadır. Bu endekslerinden biri ise 1987 Aralık tarihinden itibaren TCMB'nin ekonomide ağırlığı olan özel sektör kuruluşlarının üst düzey yöneticileri ile yapmış olduğu İktisadi Yönelim Anketi sonucu oluşan Reel Kesim Güven Endeksi (RKGE)'dir (Korkmaz ve Çevik, 2009: 25-27). Bu endeks ile üretim, siparişler, istihdam, stoklar, satış fiyat, birim maliyeti, kapasite kullanım oranı, üretici fiyatları enflasyonu, kredi faiz oranı ve genel gidişat gibi konularda reel sektör temsilcilerinin eğilim ve beklentileri ortaya konmaktadır. RKGE'nin 100'ün üstüne çıkması ekonomik faaliyete ilişkin güvenin arttğını, 100'ün altına inmesi ise ekonomik faaliyete ilişkin güvenin azaldığını göstermektedir (TCMB İktisadi Yönelim Anketi ve Reel Kesim Güven Endeksi, 2016: 2). Dolayısıyla beklentileri ölçen bu endeksin hisse senedi piyasaları ile ilişkili olabileceğini düşünmek doğaldır. Nitekim bilindiği üzere, özellikle hisse senedi piyasalarında yatırımcılar tarafindan beklentiler satın alınmaktadır. Burada beklentiler şirketin ekonomideki olumlu görünüm ile beraber gelecekte daha fazla nakit akışı sağlayacağını ve dolayısıyla karlılık ile firma değerini arttıracağını ifade etmektedir.

Bu çalışmada, RKGE ile Borsa İstanbul sektör endeksi getirileri (XUSIN, XGIDA, XTEKS, XKAGT, XKMYA, XTAST, XMANA, XMESY, XUHIZ, XELKT, XULAS, XTRZM, XTCRT, XUMAL, XBANK, XFINK, XGMYO, XUTEK) arasındaki uzun ve kısa dönemli ilişkiler araştrılmıştr. Literatürde RKGE ile özellikle de sektör endeksleri arasındaki ilişkiyi araştıran çalışmaların oldukça sınırlı sayıda olduğu belirlenmiştir. Bu açıdan çalışmanın literatüre katkı sağlayacağı tahmin edilmektedir.

\section{Literatür Taraması}

Literatürde farklı güven endeksleri ile hisse senedi fiyatları arasındaki ilişkiyi araşttran pek çok çalışma yapılmış ve bu çalışmaların birçoğunda ülkeler için temel gösterge olarak kabul edilen borsa endeksleri kullanılmıştır. Örneğin, Otoo (1999) ABD'de 1980-1999 dönemi için hisse senedi fiyatları ile tüketici güveni arasındaki ilişkiyi irdeleyen ilk çalışmayı yapmıştır. Granger nedensellik testi sonuçları hisse senedi fiyatlarındaki değişimin tüketici güvenini etkilediğini göstermiş ve hisse senetlerindeki hareketlerin öncü bir gösterge olarak kullanılabileceğini ifade etmiştir. Jansen ve Nahuis (2003) ise Otoo (1999)'nun çalışmasını 11 Avrupa ülkesini ele alarak 1986-2001 dönemi için test etmişler ve dokuz ülkede hisse senedi fiyatlarındaki değişim ile tüketici güveni arasında pozitif bir ilişki olduğunu saptamışlardır. Fisher ve Statman (2003) ABD'de 1977-2000 dönemi için 2 farklı tüketici güven endeksi ile hisse senedi getirileri arasındaki ilişkiyi ABD açısından incelemişler ve tüketici güveninin hisse senedi getirilerini öngörmek açısından önemli bir faktör olduğunu ayrıca iki değişken arasında pozitif yönlü bir ilişki olduğunu tespit etmişlerdir. Christ ve Bremmer (2003) 19782003 dönemi için $A B D$ 'de tüketici güven endeksinin, Dow Jones, S\&P 500 ve NASDAQ endeksleri ile olan ilişkisini test etmişler ve sonuç olarak tüketici güvenin hisse senedi endeksleri üzerinde etkisi olduğunu ortaya koymuşlardır. Brown ve Cliff (2004) ise ABD'de tüketici güveni ile hisse senedi piyasası arasındaki ilişkiyi 19651998 dönemi için incelemiş ve hisse senedi getirileri ile güven arasında pozitif yönlü bir ilişki olduğu sonucuna ulaşmışlardır. Ayrıca, borsa getirilerinin güvendeki değişimi tahmin etmek açısından önemli bir faktör olduğunu vurgulamışlardır. Qiu ve Welch (2004) ABD'de 2 farklı tüketici güven endeksi ile hisse senedi getirileri arasındaki ilişkiyi araştırmışlar ve Michigan Tüketici Güven Endeksi'nin hisse senedi getirilerini açıklama kabiliyetinin yüksek olduğunu saptamışlardır. Ghosh ve Clayton (2004) 1990-2001 yıllarını kapsayan çalışmalarında tüketici güven endeksi ile S\&P 500 endeksi arasındaki ilişkiyi incelemişler ve sonuç olarak tüketici güven endeksi ile S\&P 500 endeksi arasında eşbütünleşme ilişkisinin bulunduğunu ortaya 
koymuşlardır. Charoenrook (2005) 1979-2003 dönemi için tüketici güvenindeki yıllık değişimler ile hisse senedi piyasası getirileri arasında herhangi bir ilişki olup olmadığını incelemiştir. Çalışma sonucunda tüketici güveninin hisse senetlerinden elde edilecek getirilerin tahmininde önemli bir değişken olduğu belirlenmiştir. Lin vd. (2005) Avustralya'da 1974-2003 dönemi için tüketici güveni ile hisse senedi sektör endeksleri arasındaki ilişkiyi incelemişlerdir. Yapılan analizler sonucunda özellikle enerji, ham madde, mali ve bilgi teknolojileri sektörlerinin güvene karşı daha duyarlı oldukları tespit edilmiştir. Bremmer (2008) 9 hisse senedi piyasa endeksi ile tüketici güveni arasındaki ilişkiyi farklı dönemleri ele alarak analize tabi tutmuş ve hisse senedi piyasa endeksleri ile tüketici güveni arasında bir eşbütünleşme ilişkisinin olmadığını belirlemiştir. Kısa dönemde ise hisse senedi endekslerinin tüketici güveninin Granger nedeni olduğu ifade edilmiştir. Schmeling (2009) 1985-2005 dönemi için 18 ülkeyi dikkate alarak yatırımcı güveni ile hisse senetlerinin gelecekteki getirileri arasındaki ilişkiyi incelemiş ve iki değişken arasında ters yönlü bir ilişki olduğu tespit edilmiştir.

Chen (2011) ise 1978-2009 dönemi için ABD'de güven ile hisse senedi piyasası hareketleri arasındaki ilişkiyi incelemiş ve ayı piyasasındayken hisse senetlerinin güvene karşı daha duyarlı olduğunu saptamıştır. Ni vd. (2015) Çin'de 2005-2013 dönemini ele alarak hisse senedi getirileri ile yatırımcı duyarlılı̆ı arasındaki ilişkiyi incelemişler ve duyarlılığın etkisinin 1 aydan 24 aya kadar istatistiksel açıdan anlamlı olduğunu ifade etmişlerdir. Getirisi yüksek hisse senetlerinde ise etkinin kısa vadede pozitif, uzun vadede ise negatif olduğunu vurgulamışlardır. Marczak ve Beissinger (2016) ABD'de 1970-2014 dönemini ele alarak yatırımcı duyarlılığı ile hisse senedi getirileri arasındaki ilişkiyi araştırmış ve çalışmada 3 aya kadar yatırımcı duyarlıığının getirilerin nedeni olduğunu, 3 aydan sonra ise getirilerin yatırımcı duyarlıığının nedeni olduğunu ifade etmişlerdir.

Türkiye'de güven endeksleri ile hisse senedi endeksleri arasındaki ilişkiyi inceleyen çalışmalarda ise; Kandır (2006) 2002-2005 dönemi için 28 mali sektör şirketlerinin getirilerini kullanarak CNBC-e tüketici güven endeksinin BIST mali sektör şirketlerinin hisse senedi getirilerini tahmin etme kabiliyetini test etmiştir. Elde edilen sonuçlar tüketici güven endeksinin mali sektör hisse senetlerinin çoğunluğu için önemli bir faktör olduğunu ortaya koymuştur. Korkmaz ve Çevik (2007) 2002-2007 yılları arasında CNBC-e, TCMB Tüketici Güven ve Reel Kesim Güven Endeksleri ile BIST-100, Dolar ve Euro döviz kurları arasındaki nedensellik ilişkisini araştırmışlardır. Yapılan analizler sonucunda ise BIST-100 getirisinin CNBC-e ve TCMB güven endeksleri ile pozitif ilişkili olduğu belirlenmiştir. Ancak Reel Kesim Güven Endeksi ile BIST-100 arasında bir nedensellik ilişkisi tespit edilememiştir. Olgaç ve Temizel (2008) 2004-2007 yılları arasını dikkate alarak BIST-30 Endeksi ile TCMB Tüketici Güven Endeksi arasındaki ilişkiyi araştırmıştır. Yapılan analizler sonucunda BIST-30 endeksinin güven endeksi üzerinde pozitif etkisi olduğu belirlenmiştir. Korkmaz ve Çevik (2009) 1987-2008 dönemi için BIST-100 endeks getirisi ile reel kesim güven endeksi arasındaki nedensellik ilişkisini test etmiş ve BIST-100 endeks getirisi ile güven endeksi arasında geri bildirim etkisinin olduğunu ve eş zamanlı olarak birbirlerini etkilediklerini saptamışlardır.

Görmüş ve Güneş (2010) 2002-2008 dönemi için tüketici güven endeksi ile hisse senetleri ve döviz kurları arasındaki ilişkiyi incelemiş tüketici güveninin hisse senetleri ve döviz kuru üzerinde anlamlı etkisi olduğunu bulmuşlardır. Topuz (2011) 2004-2009 yılları arasını dikkate alarak tüketici güveni ve hisse senedi fiyatları arasındaki nedensellik ilişkisini incelemiş ve hisse senetlerinin tüketici güveninin Granger nedeni olduğunu tespit etmiştir. Arısoy (2012) 2005-2012 dönemi için Türkiye'de tüketici ve reel kesim güven endeksinin reel ekonomi üzerindeki etkilerini incelemiştir. Elde edilen sonuçlar reel kesim güven endeksinin, borsa endeksinden kaynaklanan bir şoka azalma yönünde bir tepki gösterdiğini ortaya koymuştur. Illaveten reel kesim güven endeksindeki bir şok karşısında borsa endeksinin tepkisinin ilk iki aylık zaman diliminde azaldığı, üçüncü aydan beşinci aya toparlanıp daha sonra ise tekrardan azalarak ortadan kalktığı vurgulanmıştır. Bolaman ve Mandacı (2014) 2003-2012 dönemi için finansal kriz dönemini göz önüne alarak tüketici güveni ile borsa arasındaki ilişkiyi incelemişler ve her iki değişen arasında uzun dönemli bir ilişki olduğunu ortaya koymuşlardır. Kale ve Akkaya (2016) 2004-2015 yılları arasını dikkate alarak tüketici güveni, reel sektör güveni ve beş farklı hisse senedi endeksi (BIST-100, mali, sınai, hizmet ve teknoloji) arasındaki ilişkiyi incelemişlerdir. Çalışmadan elde edilen bulgular, tüketici güveninden hisse senedi getirilerine doğru bir nedensellik ilişkisinin bulunmadığını ancak hisse senedi getirilerinin tüketici güvenini olumlu yönde etkilediğini ortaya koymaktadır. 


\section{Veri Seti ve Yöntem}

Borsa İstanbul sektör endeks getirileri ile ve RKGE arasındaki ilişkinin, 2007:01-2016:11 dönemi için test edildiği bu çalışmada aşağıdaki modelden yararlanılmıştır.

$$
\text { Endeks }_{t}=a_{0}+a_{1} R K G E_{t}+v_{t}
$$

Burada endeks $s_{t}$ ilgili Borsa İstanbul endeks getirisini, RKGE $E_{t}$ ise reel kesim güven endeksini göstermektedir. Çalışmada her iki seri de mevsimsellikten arındırılmış ve logaritmaları alınmıştır. Logaritmanın alınması ile varyans stabilize olmakta ve aykırı gözlemlerin etkileri azalmaktadır (Türe ve Akdi, 2005: 6; Kızılgöl, 2011: 19). Borsa endekslerine ilişkin veriler Borsa İstanbul'dan, RKGE'ne ilişkin veriler ise TCMB Elektronik Veri Dağıtım Sistemi'nden elde edilmiştir. Tablo 1'de çalışmada yer alan Borsa İstanbul endeksleri gösterilmiştir.

Tablo 1. Çalışmada Yer Alan Endeksler

\begin{tabular}{cccc}
\hline BIST Kodu & Endeks Adı & BIST Kodu & Endeks Adı \\
\hline XUSIN & BIST Sınai & XELKT & BIST Elektrik \\
\hline XGIDA & BIST Gıda ve İçecek & XULAS & BIST Ulaştırma \\
\hline XTEKS & BIST Tekstil ve Deri & XTRZM & BIST Turizm \\
\hline XKAGT & BIST Orman Kâğıt Basım & XTCRT & BIST Ticaret \\
\hline XKMYA & BIST Kimya Petrol Plastik & XUMAL & BIST Mali \\
\hline XTAST & BIST Taş Toprak & XBANK & BIST Banka \\
\hline XMANA & BIST Metal Ana & XFINK & BIST Finansal Kiralama \\
\hline XMESY & BIST Metal Eşya Makine & XGMYO & BIST GMYO \\
\hline XUHIZ & BIST Hizmetler & XUTEK & BIST Teknoloji
\end{tabular}

Çalışmada borsa endekslerine ilişkin aylık getiriler ise;

$$
R_{t}=\ln \left(\frac{P_{t}}{P_{t-1}}\right)
$$

formülü ile hesaplanmıştır. Burada $R_{t}$; ilgili endeksin $t$ dönemi doğal logaritmik getiri değerini, $P_{t}$; ilgili endeksin $\mathrm{t}$ dönemi kapanış değerini ve $\mathrm{P}_{\mathrm{t}-1}$; ilgili endeksin $\mathrm{t}-1$ dönemindeki kapanış değerini göstermektedir. Çalışmada öncelikle serilerin durağan oldukları seviyeler sahte regresyon problemi ile karşılaşmamak adına Genişletilmiş Dickey-Fuller (ADF) ve Phillips-Perron (PP) birim kök testleri yardımılla belirlenmiştir. Birim kök testleri sonuçları, serilerin aynı düzeyde durağan olmadıklarını gösterdiğinden çalışmada Engle-Granger (1987) veya Johansen (1988) ve Johansen ve Juselius (1990) eşbütünleşme testlerinin yerine Pesaran vd. (2001) tarafindan geliştirilen Sınır Testi kullanılmıştır. Sınır testinde öncelikle (3) numaralı kısıtsız hata düzeltme modeli (unrestricted error correction model UECM) tahmin edilmiştir.

$$
\Delta \mathrm{Y}_{\mathrm{t}}=\alpha_{0}+\sum_{i=1}^{p} \alpha_{1 \mathrm{i}} \Delta \mathrm{Y}_{\mathrm{t}-\mathrm{i}}+\sum_{i=0}^{p} \alpha_{2 \mathrm{i}} \Delta \mathrm{X}_{\mathrm{t}-\mathrm{i}}+\alpha_{3} \mathrm{Y}_{\mathrm{t}-1}+\alpha_{4} \mathrm{X}_{\mathrm{t}-1}+\mu
$$

Yukarıdaki (3) numaralı denklemde y; ilgili Borsa İstanbul endeksini, x; RKGE'ni, $\alpha_{0}$; sabit terimi, $\alpha_{1}$, $\alpha_{2 i}, \alpha_{3 i}, \alpha_{4} ;$ katsayıları, $\mu$; hata terimini göstermektedir. Uzun dönem ilişkinin varlığı serilerin birinci dönem gecikmelerine $\mathrm{F}$ testi yapılarak belirlenir. Eğer hesaplanan F istatistiği Pesaran vd. (2001)'deki tablo alt ve üst kritik değerleri ile karşılaştırılır. Eğer hesaplanan F istatistiği Pesaran alt kritik değerinden küçükse, seriler arasında eşbütünleşme ilişkisinin olmadığına karar verilir. Hesaplanan $F$ istatistiği alt ve üst kritik değerler arasında ise kesin bir yorum yapılamamakta ve diğer eşbütünleşme testleri yaklaşımlarına başvurulması gerekmektedir. Diğer yandan, hesaplanan $\mathrm{F}$ istatistiği üst kritik değerin üzerinde olduğu durumda ise seriler arasında eşbütünleşme ilişkisinin olduğu sonucuna varılır (Çetintaş ve Bektaş, 2008: 39). Değişkenler arasında eşbütünleşme ilişkisi ortaya konduktan sonra uzun ve kısa dönem ilişkileri tespit etmek amacıyla (4.1) 
numaralı denklem yardımıyla ARDL modelleri kurulmuştur. Burada öncelikle bağımlı ve bağımsız değişkenlerin gecikme uzunlukları AIC bilgi kriteri yardımıyla tespit edilir. Daha sonra seçilen ARDL modelinden faydalanılarak uzun dönem katsayıları ve standart hataları elde edilir.

$$
\mathrm{Y}_{\mathrm{t}}=\alpha_{0}+\sum_{i=1}^{p} \alpha_{1 \mathrm{i}} \mathrm{Y}_{\mathrm{t}-\mathrm{i}}+\sum_{i=0}^{q} \alpha_{2 \mathrm{i}} X_{\mathrm{t}-\mathrm{i}}+\mu
$$

(4.1) numaralı denklem kullanılarak uzun dönem eşitliği aşağıdaki şekilde hesaplanır.

$$
\mathrm{Y}_{\mathrm{t}}=\left[\alpha_{0} /\left(1-\sum_{i=1}^{p} \alpha_{1 i}\right)\right]+\left[\sum_{i=0}^{q} \alpha_{2 i} /\left(1-\sum_{i=1}^{p} \alpha_{1 i}\right)\right] X_{t}+\mu
$$

Seriler arasındaki kısa dönem ilişkisi ise ARDL yaklaşımına dayalı hata düzeltme modeli ile araştırılmıştır.

$$
\Delta \mathrm{Y}_{\mathrm{t}}=\alpha_{0}+\alpha_{1} \mathrm{ECT}_{\mathrm{t}-1}+\sum_{i=1}^{p} \alpha_{2 \mathrm{i}} \Delta \mathrm{Y}_{\mathrm{t}-\mathrm{i}}+\sum_{i=0}^{p} \alpha_{3 \mathrm{i}} \Delta \mathrm{X}_{\mathrm{t}-\mathrm{i}}+\mu_{\mathrm{t}}
$$

(5) numaralı denklemde $\mathrm{ECT}_{\mathrm{t}-1}$ değişkeni uzun dönem ilişkisinden elde edilen hata terimleri serisinin bir dönem gecikmeli değeridir. $\alpha_{1}$ hata düzeltme teriminin katsayısını göstermektedir. Bu katsayının negatif ve anlamlı olması beklenmektedir. Katsayının istatistiksel açıdan anlamlı olması sapmanın varlığını gösterir. Hata düzeltme katsayısının 1 'den küçük olması ise modelin dengeli olduğunu, negatif işaretli olması da dengeden sapmanın olması halinde tekrar dengeye doğru hareketin olduğunu göstermektedir (Bozdağlıoğlu, 2007: 222).

Seriler arasındaki nedensellik ilişkisi ise Toda ve Yamamoto tarafindan geliştirilen nedensellik testi ile incelenmiştir. Bu nedensellik testinde serilerin koentegre olması durumu önemli değildir (Toda ve Yamamoto, 1995). VAR modeline dayanan bu test iki aşamadan oluşmaktadır. Birinci aşamada, serilerin maksimum durağanlık derecesi $\left(d_{\max }\right)$ ve en uygun gecikme uzunluğunu $(k)$ belirlenmektedir. Burada en uygun gecikme uzunluğunun belirlenebilmesi için $\mathrm{AIC}$ ve $\mathrm{SCl}$ bilgi kriterlerinden yararlanılmaktadır. İinci aşamada ise en uygun gecikme uzunluğuna eklenen $d_{\max }$ gecikmelerine karşı gelen katsayılar ihmal edilerek Wald testi uygulanmaktadır (Ulusoy vd. 2016: 19).

$$
\begin{aligned}
& \mathrm{Y}_{\mathrm{t}}=\lambda_{1}+\sum_{i=1}^{k} \alpha_{1 i} \mathrm{Y}_{\mathrm{t}-\mathrm{i}}+\sum_{j=k+1}^{d_{\max }} \alpha_{2 j} \mathrm{Y}_{\mathrm{t}-\mathrm{j}}+\sum_{i=1}^{k} \beta_{1 i} \mathrm{X}_{\mathrm{t}-\mathrm{i}}+\sum_{j=k+1}^{d_{\max }} \beta_{2 j} \mathrm{X}_{\mathrm{t}-\mathrm{j}}+\mathrm{e}_{1 \mathrm{t}} \\
& \mathrm{X}_{\mathrm{t}}=\lambda_{2}+\sum_{i=1}^{k} \alpha_{2 i} \mathrm{Y}_{\mathrm{t}-\mathrm{i}}+\sum_{j=k+1}^{d_{\max }} \alpha_{2 j} \mathrm{Y}_{\mathrm{t}-\mathrm{j}}+\sum_{i=1}^{k} \beta_{2 i} \mathrm{X}_{\mathrm{t}-\mathrm{i}}+\sum_{j=k+1}^{d_{\max }} \beta_{2 j} \mathrm{X}_{\mathrm{t}-\mathrm{j}}+\mathrm{e}_{2 \mathrm{t}}
\end{aligned}
$$

\section{Bulgular}

Çalışmada kullanılan serilere ait tanımlayıcı istatistikler Tablo 2' de gösterilmiştir. Tabloya göre çalışma dönemi boyunca BIST Turizm endeksi hariç diğer tüm endekslerden yatırımcıların pozitif ortalama getiriler elde ettiği saptanmıştır. Oynaklık açısından endeksler değerlendirildiğinde ise en oynak endeksin BIST Ulaştırma olduğu belirlenmiştir. Ayrıca yer alan tüm serilerin (BIST Elektrik hariç) çarpıklık katsayılarının genel olarak sola çarpık, basıklık katsayıları 3'den büyük olduğu için ise leptokurtik (kalın kuyruk) dağılım gösterdikleri tespit edilmiştir.

Tablo 3'te ise, RKGE ve BIST sektör endeksleri için elde edilen ADF ve PP birim kök testi sonuçları sunulmuştur. Buna göre $\% 5$ anlamlılık düzeyinde, çalışmada yer alan BIST sektör endekslerinin tümünün seviyesinde, RKGE'nin ise 1. farkında durağan olduğu görülmektedir. Bu nedenle seriler arasındaki uzun dönemli ilişki Sınır testi yardımı ile analiz edilmiştir. 
Reel Kesim Güven Endeksi ile Borsa İstanbul Sektör Endeksleri Arasındaki İlişkinin Test Edilmesi

Tablo 2. Tanımlayıcı İstatistikler

\begin{tabular}{cccccccc}
\hline Değişkenler & Ortalama & Maksimum & Minimum & St. Sapma & Çarpıklık & Basıklık & J-Bera \\
\hline LRKGE & 4,636 & 4,842 & 4,068 & 0,127 & $-2,775$ & 11,389 & $639,98^{\mathrm{a}}$ \\
\hline LXUSIN & 0,007 & 0,147 & $-0,233$ & 0,061 & $-1,096$ & 5,673 & $59,27^{\mathrm{a}}$ \\
\hline LXGIDA & 0,008 & 0,145 & $-0,189$ & 0,061 & $-0,671$ & 4,062 & $14,52^{\mathrm{a}}$ \\
\hline LXTEKS & 0,007 & 0,192 & $-0,244$ & 0,072 & $-0,375$ & 4,268 & $10,75^{\mathrm{a}}$ \\
\hline LXKAGT & 0,001 & 0,261 & $-0,277$ & 0,087 & $-0,209$ & 4,685 & $14,94^{\mathrm{a}}$ \\
\hline LXKMYA & 0,009 & 0,222 & $-0,232$ & 0,070 & $-0,579$ & 5,014 & $26,77^{\mathrm{a}}$ \\
\hline LXTAST & 0,002 & 0,134 & $-0,232$ & 0,063 & $-0,922$ & 4,112 & $23,01^{\mathrm{a}}$ \\
\hline LXMANA & 0,009 & 0,216 & $-0,297$ & 0,083 & $-0,541$ & 4,665 & $19,55^{\mathrm{a}}$ \\
\hline LXMESY & 0,010 & 0,210 & $-0,359$ & 0,084 & $-1,127$ & 6,352 & $80,91^{\mathrm{a}}$ \\
\hline LXUHIZ & 0,006 & 0,182 & $-0,212$ & 0,057 & $-0,755$ & 5,636 & $45,76^{\mathrm{a}}$ \\
\hline LXELKT & 0,003 & 0,267 & $-0,262$ & 0,088 & 0,030 & 3,332 & 0,57 \\
\hline LXULAS & 0,012 & 0,224 & $-0,342$ & 0,100 & $-0,423$ & 4,129 & $9,87^{\mathrm{a}}$ \\
\hline LXTRZM & $-0,005$ & 0,232 & $-0,351$ & 0,091 & $-0,760$ & 5,228 & $36,06^{\mathrm{a}}$ \\
\hline LXTCRT & 0,011 & 0,159 & $-0,313$ & 0,062 & $-1,261$ & 9,049 & $212,9^{\mathrm{a}}$ \\
\hline LXUMAL & 0,004 & 0,182 & $-0,265$ & 0,080 & $-0,432$ & 4,053 & $9,20^{\mathrm{b}}$ \\
\hline LXBANK & 0,003 & 0,220 & $-0,248$ & 0,085 & $-0,200$ & 3,463 & 1,86 \\
\hline LXFINK & 0,006 & 0,198 & $-0,395$ & 0,086 & $-1,401$ & 7,544 & $141,29^{\mathrm{a}}$ \\
\hline LXGMYO & 0,002 & 0,186 & $-0,349$ & 0,081 & $-1,172$ & 6,675 & $94,20^{\mathrm{a}}$ \\
\hline LXUTEK & 0,015 & 0,203 & $-0,253$ & 0,080 & $-0,363$ & 3,786 & $5,67^{\mathrm{c}}$ \\
\hline a, b, c SIraSIY $\% 1, \% 5$ & $\% 10$ & & & &
\end{tabular}

Tablo 3. Değişkenlere Ait Birim Kök Sonuçları

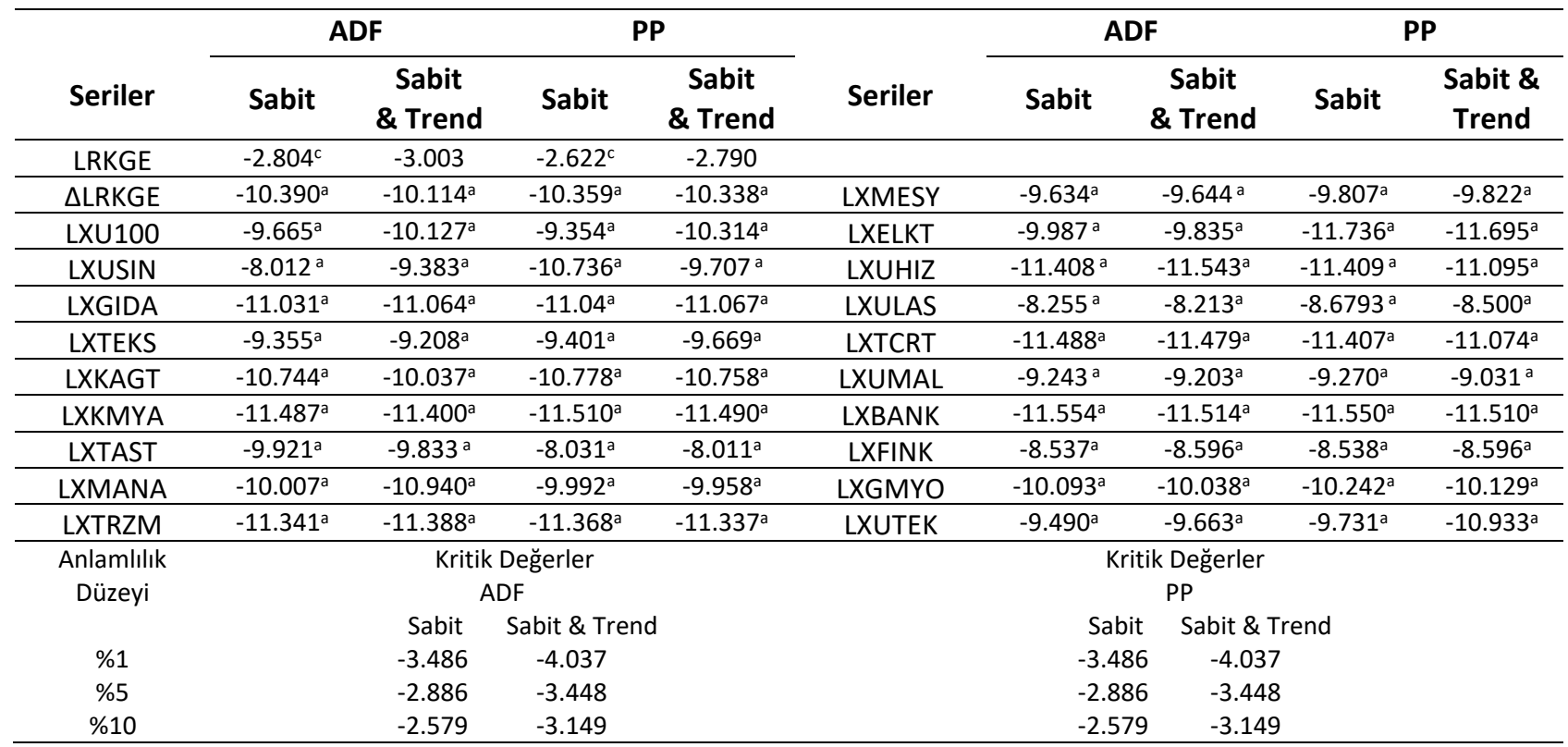

a, c sırasıyla \%1 ve \%10 anlamlılık düzeylerini göstermektedir.

\subsection{Eşbütünleşme Testi}

Bu aşamada öncelikle yapılması gereken optimal gecikme uzunluğunun belirlenmesidir. Değişkenler farklı gecikme kombinasyonları ile sınanarak, bilgi kriterlerine göre (AIC, SIC veya HQ) optimal gecikme uzunluğu belirlenmiştir. Gecikme uzunluğu belirlendikten sonra 3 numaralı eşitlikten yararlanılarak Sınır Testi yaklaşımıyla seriler arasında eşbütünleşme ilişkileri araştırılmıştır. Tablo 4 sınır testi sonuçlarını göstermektedir. F istatistikleri Wald testi yardımıyla $H_{0}=\alpha_{3}=\alpha_{4}=0$ hipotezinden hesaplanmıştı. Tablo 4'te görüldüğü üzere hesaplanan F istatistikleri tüm modeller için Pesaran'ın üst kritik değerini aşttğı için ayrı ayrı 18 BIST endeksinin tümünün RKGE ile eşbütünleşik olduğu tespit edilmiştir. 
Tablo 4. Sınır Testi Sonuçları

\begin{tabular}{|c|c|c|c|}
\hline \multicolumn{4}{|c|}{ LRKGE (Bağımsız Değişken) } \\
\hline Bağımlı Değişken & F istatistiği Değeri & Bağımlı Değişken & F istatistiği Değeri \\
\hline LXUSIN & $34,430^{a}$ & LXULAS & $23,884^{a}$ \\
\hline LXGIDA & $61,557^{a}$ & LXTRZM & $37,993^{a}$ \\
\hline LXTEKS & $32,560^{\mathrm{a}}$ & LXTCRT & $54,787^{a}$ \\
\hline LXKAGT & $50,656^{a}$ & LXUMAL & $18,111^{\mathrm{a}}$ \\
\hline LXKMYA & $37,182^{\mathrm{a}}$ & LXBANK & $18,081^{\mathrm{a}}$ \\
\hline LXTAST & $8,787^{a}$ & LXFINK & $28,023^{a}$ \\
\hline LXMANA & $37,182^{a}$ & LXGMYO & $37,638^{a}$ \\
\hline LXMESY & $34,994^{a}$ & LXUTEK & $36,476^{a}$ \\
\hline LXUHIZ & $51,406^{a}$ & LXELKT & $33,343^{a}$ \\
\hline
\end{tabular}

a \%1 anlamlılık düzeyini göstermektedir. a \%1 anlamlıık düzeyini göstermektedir. \%5 anlamlılık anlamlılık düzeyindeki kritik değerler alt sınır için 4,94, üst sınır için 5,73 değerleridir. Kritik değerler Pesaran vd. (2001: 300) Tablo Cl(iii) Case III'den alınmıştır.

Seriler arasında eşbütünleşme ilişkileri tespit edildiğinden sonra uzun ve kısa dönem ilişkileri belirlemek için amacıyla ARDL (Autoregressive Distribution Lag) modellerine geçilmiştir. Tablo 5'te 4.1 numaralı eşitlikten yararlanılarak elde edilen ARDL Modeli tahmin sonuçları gösterilmiştir.

Tablo 5. Değişkenler için Hesaplanan ARDL Modeli Tahmin Sonuçları

\begin{tabular}{|c|c|c|c|c|c|c|}
\hline Değişkenler & Katsayı & $\mathrm{t}$ istatistiği & Değişkenler & Model & Katsayı & t istatistiği \\
\hline LXUSIN(-1) & -0.015 & -0.157 & LXTEKS(-1) & \multirow[t]{4}{*}{ ARDL(1,1) } & 0.050 & 0.519 \\
\hline LRKGE & 0.531 & $3.572^{\mathrm{a}}$ & LRKGE & & 0.602 & $3.536^{\mathrm{a}}$ \\
\hline LRKGE (-1) & -0.488 & $-3.430^{a}$ & LRKGE(-1) & & -0.622 & $-3.744^{a}$ \\
\hline $\mathrm{C}$ & -0.189 & -0.924 & c & & 0.097 & 0.417 \\
\hline$R^{2}=0.12$ White $=1.07 \mathrm{LM}(1)=0.33$ & \multicolumn{2}{|c|}{$4 \quad L M(12)=1.119$} & \multicolumn{4}{|c|}{$\mathrm{R}^{2}=0.146$ White $=0,996 \mathrm{LM}(1)=0.368 \mathrm{LM}(12)=1.012$} \\
\hline Değișkenler & Katsayı & $\mathrm{t}$ istatistiği & Değișkenler & Model & Katsayı & t istatistiği \\
\hline LXGIDA(-1) & -0.238 & $-2.605^{b}$ & LXKAGT(-1) & \multirow[t]{5}{*}{ ARDL(1,2) } & $-0.194^{\mathrm{b}}$ & -1.987 \\
\hline LRKGE & 0.173 & 1.149 & LRKGE & & 0.254 & 1.100 \\
\hline LRKGE(-1) & 0.192 & 0.787 & LRKGE(-1) & & 0.264 & 0.729 \\
\hline LRKGE(-2) & -0.356 & $-2.422^{b}$ & LRKGE(-2) & & $-0.530^{b}$ & -2.490 \\
\hline c & -0.0342 & -0.164 & c & & 0.053 & 0.177 \\
\hline$R^{2}=0.12 \quad$ White $=0,993 \quad L M(1)=0.213$ & $\operatorname{LM}(12)=0,744$ & & $R^{2}=0.109$ White $=C$ & $\operatorname{LM}(1)=0.210$ & $\operatorname{LM}(12)=1.00$ & \\
\hline Değișkenler & Katsayı & $\mathrm{t}$ istatistiği & Değișkenler & Model & Katsayı & $\mathrm{t}$ istatistiği \\
\hline LXUHIZ(-1) & -0.217 & $-2.210^{c}$ & LXKMYA(-1) & \multirow{4}{*}{$\operatorname{ARDL}(1,1)$} & -0.034 & -0.352 \\
\hline LRKGE & 0.381 & $2.801^{\mathrm{a}}$ & LRKGE & & 0.581 & $3.457^{\mathrm{a}}$ \\
\hline LRKGE(-1) & -0.381 & $-2.858^{\mathrm{a}}$ & LRKGE(-1) & & -0.527 & $-3.254^{\mathrm{a}}$ \\
\hline $\mathrm{C}$ & 0.007 & 0.039 & $\mathrm{C}$ & & -0.240 & -1.013 \\
\hline \multicolumn{3}{|c|}{$R^{2}=0.078$ White $=0,542 L M(1)=0.141 L M(12)=1.010$} & \multicolumn{4}{|c|}{$R^{2}=0.106$ White $=1.060 \mathrm{LM}(1)=0.536 \mathrm{LM}(12)=1.444$} \\
\hline Değişkenler & Katsayı & t istatistiği & Değişkenler & \multirow{5}{*}{$\operatorname{ARDL}(1,1)$} & Katsayı & $\mathrm{t}$ istatistiği \\
\hline LXTRZM(-1) & -0.075 & -0.741 & LXELKT(-1) & & 0.020 & 0.211 \\
\hline LRKGE & 0.460 & $2.059^{b}$ & LRKGE & & $0.621^{\mathrm{a}}$ & 2.931 \\
\hline LRKGE(-1) & -0.534 & $-2.414^{b}$ & LRKGE(-1) & & $-0.641^{a}$ & $-3.09^{\mathrm{a}}$ \\
\hline $\mathrm{c}$ & 0.336 & 1.092 & $\mathrm{c}$ & & 0.095 & 0.325 \\
\hline \multicolumn{3}{|c|}{$R^{2}=0.219$ White $=0.604 \quad L M(1)=0.196 \quad L M(12)=1.026$} & \multicolumn{4}{|c|}{$\mathrm{R}^{2}=0.096$ White $=1,101 \mathrm{LM}(1)=0.496 \mathrm{LM}(12)=1.381$} \\
\hline Değișkenler $\quad$ Model & Katsayı & $\mathrm{t}$ istatistiği & Değişkenler & Model & Katsayı & $t$ istatistiği \\
\hline LXTCRT(-1) & -0.213 & $-2.232^{\mathrm{b}}$ & $\operatorname{LXFINK(-1)}$ & \multirow{4}{*}{$\operatorname{ARDL}(1,1)$} & 0.032 & 0.302 \\
\hline LRKGE & 0.785 & $5.427^{\mathrm{a}}$ & LRKGE & & 0.565 & $2.517^{b}$ \\
\hline LRKGE(-1) & -0.793 & $-5.628^{a}$ & LRKGE(-1) & & -0.635 & $-2.883^{\mathrm{a}}$ \\
\hline $\mathrm{c}$ & 0.050 & 0.260 & c & & 0.334 & 1.183 \\
\hline \multicolumn{3}{|c|}{$R^{2}=0.219$ White $=0.604 \quad L M(1)=0.196 \quad L M(12)=1.026$} & \multicolumn{4}{|c|}{$R^{2}=0.109$ White $=1.295 \mathrm{LM}(1)=0.126 \mathrm{LM}(12)=1.084$} \\
\hline Değişkenler & Katsayı & t istatistiği & Değişkenler & Model & Katsayı & $\mathrm{t}$ istatistiği \\
\hline LXULAS(-1) & 0.076 & 0.748 & LXMESY(-1) & \multirow[t]{7}{*}{ ARDL(1,4) } & -0.081 & -0.762 \\
\hline LXULAS(-2) & 0.087 & 0.938 & LRKGE & & 0.937 & $4.330^{\mathrm{a}}$ \\
\hline LXULAS(-3) & 0.080 & 0.866 & LRKGE(-1) & & -0.968 & $-2.852^{\mathrm{a}}$ \\
\hline LXULAS(-4) & 0.194 & 2.129 & LRKGE(-2) & & 0.369 & 1.025 \\
\hline LRKGE & 0.344 & 1.451 & LRKGE(-3) & & -0.058 & -0.173 \\
\hline LRKGE(-1) & $-0.511^{b}$ & -2.135 & LRKGE(-4) & & -0.318 & -1.623 \\
\hline c & $0.778^{b}$ & 2.340 & c & & 0.193 & 0.677 \\
\hline \multicolumn{3}{|c|}{$R^{2}=0.170$ White $=0.455 \quad L M(1)=0.606 L M(12)=1.027$} & \multicolumn{4}{|c|}{$R^{2}=0.078$ White $=0,542 \mathrm{LM}(1)=0.141 \mathrm{LM}(12)=1.010$} \\
\hline Değişkenler & Katsayı & $\mathrm{t}$ istatistiği & Değişkenler & Model & Katsayı & $\mathrm{t}$ istatistiği \\
\hline LXTAST(-1) & 0.113 & 1.175 & LXMANA(-1) & ARDL(4,1) & 0.109 & 1.134 \\
\hline LXTAST $(-2)$ & -0.116 & -1.265 & LXMANA(-2) & & -0.052 & -0.547 \\
\hline $\operatorname{LXTAST}(-3)$ & 0.023 & 0.260 & LXMANA(-3) & & -0.244 & $-2.564^{b}$ \\
\hline LXTAST (-4) & 0.285 & $3.242^{\mathrm{a}}$ & LXMANA(-4) & & 0.141 & 1.455 \\
\hline LRKGE & 0.495 & $3.307^{a}$ & LRKGE & & 0.713 & $3.632^{\mathrm{a}}$ \\
\hline
\end{tabular}


Reel Kesim Güven Endeksi ile Borsa İstanbul Sektör Endeksleri Arasındaki İlişkinin Test Edilmesi

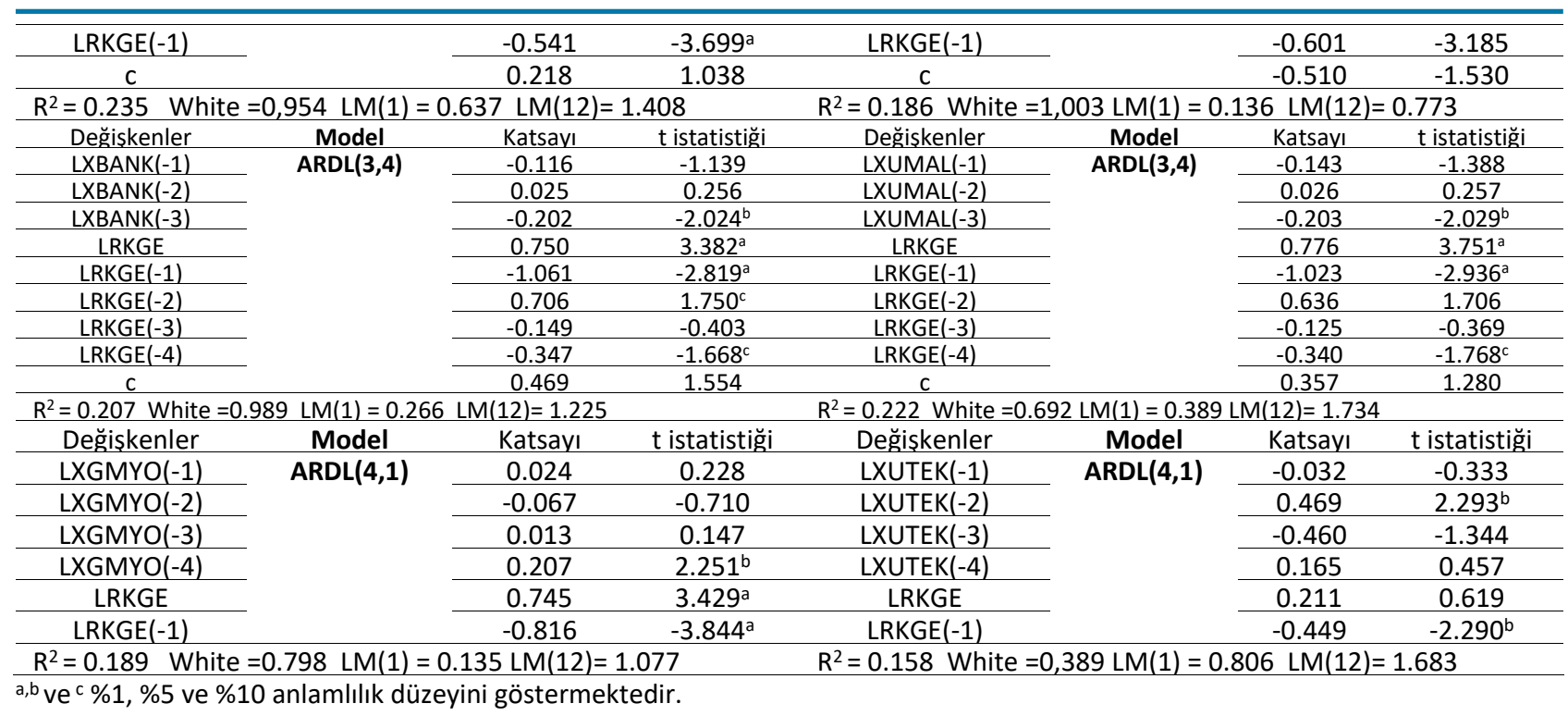

\subsubsection{Uzun Dönem Ilişki}

4.2 numaralı eşitlikten yararlanılarak hesaplanan uzun dönem katsayıları ise Tablo 6'da yer almaktadır. Tablodan görüldüğü üzere sadece XMANA'nın uzun dönem katsayısı ile RKGE arasında anlamlı bir ilişki olduğu belirlenmiştir.

Buna göre uzun dönemde RKGE'deki artı̧̧ı XMANA endeks getirisini pozitif ve istatistiksel açıdan anlamlı bir şekilde etkilediği ortaya konmuştur. Diğer tüm uzun dönem katsayıları ise istatistiksel açıdan anlamsız bulunmuştur.

Tablo 6. ARDL Modellerinden Elde Edilen Uzun Dönem Katsayıları

\begin{tabular}{|c|c|c|c|c|c|}
\hline Değişkenler & Katsayı & Değişkenler & Katsayı & Değişkenler & Katsayı \\
\hline \multicolumn{2}{|c|}{ ARDL $(1,1)$ LXUSIN } & \multicolumn{2}{|c|}{ ARDL $(4,1)$ LXULAS } & \multicolumn{2}{|c|}{ ARDL $(4,1)$ LXTAST } \\
\hline LRKGE & 0.041 & LRKGE & -0.296 & LRKGE & -0.067 \\
\hline c & -0.186 & c & 1.383 & $\mathrm{C}$ & 0.314 \\
\hline Değişkenler & Katsayı & Değişkenler & Katsayı & Değişkenler & Katsayı \\
\hline \multicolumn{2}{|c|}{ ARDL $(1,2)$ LXGIDA } & \multicolumn{2}{|c|}{ ARDL $(1,1)$ LXTRZM } & \multicolumn{2}{|c|}{ ARDL $(4,1)$ LXMANA } \\
\hline LRKGE & 0.007 & LRKGE & -0.296 & LRKGE & $0.107^{c}$ \\
\hline c & -0.027 & c & 1.383 & $c$ & $-0.488^{c}$ \\
\hline Değişkenler & Katsayı & Değişkenler & Katsayı & Değişkenler & Katsayı \\
\hline \multicolumn{2}{|c|}{ ARDL $(1,1)$ XTEKS } & \multicolumn{2}{|c|}{ ARDL $(1,1)$ LXTCRT } & \multicolumn{2}{|c|}{ ARDL $(1,4)$ LXMESY } \\
\hline LRKGE & -0.020 & LRKGE & -0.006 & LRKGE & -0.036 \\
\hline $\mathrm{C}$ & 0.102 & $\mathrm{C}$ & 0.041 & $\mathrm{C}$ & 0.178 \\
\hline Değişkenler & Katsayı & Değişkenler & Katsayı & Değişkenler & Katsayı \\
\hline \multicolumn{2}{|c|}{ ARDL $(1,2)$ LXKAGT } & \multicolumn{2}{|c|}{ ARDL $(3,4)$ LXUMAL } & \multicolumn{2}{|c|}{ ARDL $(1,1)$ LXUHIZ } \\
\hline LRKGE & -0.009 & LRKGE & -0.057 & LRKGE & 0.001 \\
\hline c & 0.045 & C & 0.270 & $\mathrm{C}$ & 0.006 \\
\hline Değişkenler & Katsayı & Değişkenler & Katsayı & Değişkenler & Katsayı \\
\hline \multicolumn{2}{|c|}{ ARDL $(1,1)$ LXKMYA } & \multicolumn{2}{|c|}{ ARDL $(3,4)$ LXBANK } & \multicolumn{2}{|c|}{ ARDL $(1,1)$ LXELKT } \\
\hline LRKGE & 0.052 & LRKGE & -0.077 & LRKGE & -0.020 \\
\hline c & -0.232 & c & 0.363 & c & 0.097 \\
\hline Değişkenler & Katsayı & Değişkenler & Katsayı & Değişkenler & Katsayı \\
\hline \multicolumn{2}{|c|}{ ARDL $(1,1)$ LXFINK } & \multicolumn{2}{|c|}{ ARDL $(4,1)$ LXGMYO } & \multicolumn{2}{|c|}{ ARDL $(4,1)$ LXUTEK } \\
\hline LRKGE & -0.073 & LRKGE & -0.087 & LRKGE & -0.061 \\
\hline $\mathrm{C}$ & 0.346 & C & 0.405 & C & 0.302 \\
\hline
\end{tabular}

c \%10 anlamlılık seviyelerini göstermektedir. 


\subsubsection{Kısa Dönem İlişki}

Değişkenler arasındaki kısa dönemli ilişkinin araştırılması için ARDL yaklaşımına dayalı hata düzeltme modelleri kurulmuş ve sonuçları Tablo 7'de gösterilmiştir. Hata düzeltme modeli sonuçlarına göre uzun dönemli katsayıların aksine kısa dönemde RKGE ile tüm BIST sektör endeksleri arasında ayrı ayrı anlamlı ilişki olduğu tespit edilmiştir. Ayrıca RKGE'deki yükselişin XULAS ve XTAST hariç tüm BIST sektör endekslerinin getirilerini pozitif yönde etkilediği belirlenmiştir.

Tablo 7. ARDL Modellerine Dayalı Hata Düzeltme Modeli Sonuçları ${ }^{2}$

\begin{tabular}{|c|c|c|c|c|c|c|c|}
\hline Değişkenler & LXUSIN & Katsayı & t istatistiği & Değişkenler & LXTEKS & Katsayı & t istatistiği \\
\hline$\triangle \mathrm{LRKGE}$ & \multirow[t]{2}{*}{ ARDL(1,1) } & 0.531 & $3.282^{\mathrm{a}}$ & $\triangle \mathrm{LRKGE}$ & \multirow[t]{2}{*}{ ARDL(1,1) } & 0.602 & $3.685^{a}$ \\
\hline $\mathrm{ECT}(-1)$ & & -0.815 & $-8.988^{a}$ & $\mathrm{ECT}(-1)$ & & -0.949 & $-9.969^{a}$ \\
\hline Değişkenler & LXGIDA & Katsayı & t istatistiği & Değişkenler & LXKAGT & Katsayı & t istatistiği \\
\hline$\triangle \mathrm{LRKGE}$ & \multirow[t]{3}{*}{ ARDL(1,2) } & 0.173 & 1.208 & $\triangle \mathrm{LRKGE}$ & \multirow[t]{3}{*}{ ARDL(1,2) } & 0.254 & 1.164 \\
\hline$\Delta$ LRKGE(-1) & & 0.356 & $2.514^{b}$ & $\Delta$ LRKGE(-1) & & 0.530 & $2.589^{b}$ \\
\hline $\mathrm{ECT}(-1)$ & & -0.938 & $-10.710^{a}$ & $\mathrm{ECT}(-1)$ & & -1.194 & $-10.437^{a}$ \\
\hline Değişkenler & LXKMYA & Katsayı & t istatistiği & Değişkenler & LXUHIZ & Katsayı & t istatistiği \\
\hline$\triangle \mathrm{LRKGE}$ & \multirow[t]{2}{*}{ ARDL(1,1) } & 0.581 & $3.586^{a}$ & $\triangle \mathrm{LRKGE}$ & \multirow[t]{2}{*}{ ARDL(1,1) } & 0.381 & $2.896^{\mathrm{a}}$ \\
\hline $\mathrm{ECT}(-1)$ & & -1.034 & $-11.653^{a}$ & $\mathrm{ECT}(-1)$ & & -1.217 & $-12.526^{a}$ \\
\hline Değişkenler & LXTCRT & Katsayı & $\mathrm{t}$ istatistiği & Değişkenler & LXFINK & Katsayı & t istatistiği \\
\hline$\triangle \mathrm{LRKGE}$ & \multirow[t]{2}{*}{ ARDL(1,1) } & 0.785 & $5.644^{\mathrm{a}}$ & $\triangle \mathrm{LRKGE}$ & \multirow[t]{2}{*}{ ARDL(1,1) } & 0.565 & $2.637^{\mathrm{a}}$ \\
\hline $\mathrm{ECT}(-1)$ & & -0.993 & $-12.932^{a}$ & ECT(-1) & & -0.967 & $-9.249^{a}$ \\
\hline Değişkenler & LXELKT & Katsayı & $\mathrm{t}$ istatistiği & Değişkenler & LXTRZM & Katsayı & t istatistiği \\
\hline$\Delta \mathrm{LRKGE}$ & \multirow[t]{2}{*}{ ARDL(1,1) } & 0.621 & $3.049^{a}$ & $\Delta \mathrm{LRKGE}$ & \multirow[t]{2}{*}{ ARDL(1,1) } & 0.460 & $2.135^{b}$ \\
\hline $\mathrm{ECT}(-1)$ & & -0.979 & $-10.088^{a}$ & $\mathrm{ECT}(-1)$ & & -1.075 & $-10.769^{a}$ \\
\hline Değişkenler & LXMESY & Katsayı & $\mathrm{t}$ istatistiği & Değişkenler & LXULAS & Katsayı & $\mathrm{t}$ istatistiği \\
\hline$\Delta \mathrm{LRKGE}$ & \multirow[t]{5}{*}{ ARDL(1,4) } & 0.937 & $4.580^{\mathrm{a}}$ & $\Delta$ LXULAS(-1) & \multirow[t]{5}{*}{ ARDL(4,1) } & -0.361 & $-3.110^{a}$ \\
\hline$\Delta$ LRKGE (-1) & & 0.007 & 0.036 & $\Delta$ LXULAS(-2) & & -0.274 & $-2.554^{b}$ \\
\hline$\Delta$ LRKGE (-2) & & 0.377 & $1.825^{c}$ & $\Delta$ LXULAS(-3) & & -0.194 & $-2.232^{b}$ \\
\hline$\Delta$ LRKGE (-3) & & 0.318 & $1.670^{c}$ & $\Delta \mathrm{LRKGE}$ & & 0.344 & 1.516 \\
\hline $\mathrm{ECM}(-1)$ & & -1.081 & $-10.339^{a}$ & $\mathrm{ECT}(-1)$ & & -0.562 & $-4.617^{a}$ \\
\hline Değişkenler & LXTAST & Katsayı & $\mathrm{t}$ istatistiği & Değişkenler & LXMANA & Katsayı & $\mathrm{t}$ istatistiği \\
\hline$\Delta$ LXTAST $(-1)$ & \multirow[t]{5}{*}{ ARDL(4,1) } & -0.193 & -1.65 & $\triangle$ LXMANA(-1) & \multirow[t]{5}{*}{ ARDL(4,1) } & 0.154 & 1.058 \\
\hline$\Delta$ LXTAST $(-2)$ & & -0.309 & $-3.086^{a}$ & DLXMANA(-2) & & 0.102 & 0.837 \\
\hline$\Delta$ LXTAST $(-3)$ & & -0.285 & $-3.415^{a}$ & $\Delta$ LXMANA(-3) & & -0.141 & -1.502 \\
\hline$\Delta \mathrm{LRKGE}$ & & 0.495 & $3.478^{a}$ & $\triangle \mathrm{LRKGE}$ & & 0.713 & $3.764^{\mathrm{a}}$ \\
\hline $\mathrm{ECT}(-1)$ & & -0.693 & $-5.181^{a}$ & $\mathrm{ECT}(-1)$ & & -1.045 & $-5.798^{a}$ \\
\hline Değişkenler & LXGMYO & Katsayı & $\mathrm{t}$ istatistiği & Değişkenler & LXUTEK & Katsayı & $\mathrm{t}$ istatistiği \\
\hline$\triangle \mathrm{LXGMYO}(-1)$ & \multirow[t]{5}{*}{ ARDL(4,1) } & -0.153 & -1.276 & $\triangle$ LXUTEK $(-1)$ & \multirow[t]{5}{*}{ ARDL(4,1) } & 0.469 & $2.412^{b}$ \\
\hline$\Delta$ LXGMYO (-2) & & -0.220 & $-2.067^{b}$ & $\Delta$ LXUTEK (-2) & & 0.073 & 0.349 \\
\hline$\triangle$ LXGMYO (-3) & & -0.207 & $-2.371^{b}$ & $\triangle$ LXUTEK (-3) & & 0.238 & 1.142 \\
\hline$\triangle \mathrm{LRKGE}$ & & 0.745 & $3.619^{a}$ & $\Delta \mathrm{LRKGE}$ & & 0.449 & $2.364^{b}$ \\
\hline $\mathrm{ECT}(-1)$ & & -0.821 & $-5.801^{a}$ & $\mathrm{ECT}(-1)$ & & -0.932 & $-9.724^{a}$ \\
\hline Değişkenler & LXUMAL & Katsayı & $\mathrm{t}$ istatistiği & Değişkenler & LXBANK & Katsayı & t istatistiği \\
\hline$\Delta$ LXUMAL(-1) & \multirow[t]{7}{*}{ ARDL(3,4) } & 0.176 & 1.220 & $\triangle$ LXBANK(-1) & \multirow[t]{7}{*}{ ARDL $(3,4)$} & 0.187 & 1.277 \\
\hline$\triangle$ LXUMAL(-2) & & 0.203 & $2.069^{b}$ & $\triangle$ LXBANK(-2) & & 0.220 & $2.247^{b}$ \\
\hline$\triangle \mathrm{LRKGE}$ & & 0.776 & $3.918^{\mathrm{a}}$ & $\triangle \mathrm{LRKGE}$ & & 0.831 & $4.381^{\mathrm{a}}$ \\
\hline$\Delta$ LRKGE (-1) & & -0.170 & -0.746 & $\Delta$ LRKGE (-1) & & -0.134 & -0.621 \\
\hline$\Delta$ LRKGE (-2) & & 0.465 & $2.088^{b}$ & $\Delta$ LRKGE $(-2)$ & & 0.446 & $2.128^{b}$ \\
\hline$\Delta$ LRKGE (-3) & & 0.340 & $1.816^{c}$ & $\Delta$ LRKGE (-3) & & 0.395 & $2.237^{\mathrm{b}}$ \\
\hline $\mathrm{ECT}(-1)$ & & -1.020 & $-7.040^{\mathrm{a}}$ & $\mathrm{ECT}(-1)$ & & -0.961 & $-6.567^{a}$ \\
\hline
\end{tabular}

a,b ve ${ }^{c} \% 1, \% 5$ ve $\% 10$ anlamlılık düzeyini göstermektedir.

Değişkenler arasındaki nedensellik ilişkisi ise, Toda-Yamamoto nedensellik testi ile sınanmış ve sonuçları Tablo 8'de sunulmuştur. Elde edilen bulgular XUSIN, XKMYA, XMANA, XMESY, XUHIZ, XULAS, XELKT, XTRZM, XTCRT, XUMAL, XTEKS, XGMYO ve XUTEK'ten RKGE'ne doğru, RKGE'nden ise XGIDA'ya doğru tek yönlü bir 
nedensellik ilişkisinin var olduğunu göstermektedir. Illaveten XKAGT, XTAST, XFINK, XUMAL ve XBANK ile RKGE arasında çift yönlü bir nedensellik ilişkisinin var olduğu belirlenmiştir.

Tablo 8. Toda-Yamamoto Nedensellik Testi Sonuçları

\begin{tabular}{|c|c|c|c|}
\hline Nedenselliğin Yönü & F ist. & Nedenselliğin Yönü & $F$ ist. \\
\hline XUSIN $\longrightarrow$ RKGE & $24.273^{a}$ & XULAS $\longrightarrow$ RKGE & $19.835^{a}$ \\
\hline RKGE $\longrightarrow$ XUSIN & 5.323 & $\rightarrow$ XULAS & 0.471 \\
\hline $\mathrm{XGIDA} \longrightarrow \mathrm{RKGE}$ & 4.214 & $\mathrm{XELKT} \longrightarrow \mathrm{RKGE}$ & $16.064^{a}$ \\
\hline RKGE $\longrightarrow$ XGIDA & $9.162^{b}$ & RKGE $\longrightarrow$ XELKT & 1.776 \\
\hline XKAGT $\longrightarrow$ RKGE & $21.580^{\mathrm{a}}$ & $\mathrm{XTRZM} \longrightarrow \mathrm{RKGE}$ & $21.813^{a}$ \\
\hline RKGE $\longrightarrow$ XKAGT & $8.757^{b}$ & RKGE $\longrightarrow$ XTRZM & 1.055 \\
\hline XKMYA $\longrightarrow$ RKGE & $17.206^{\mathrm{a}}$ & XTCRT $\longrightarrow$ RKGE & $19.654^{a}$ \\
\hline RKGE $\longrightarrow$ XKMYA & 1.447 & $\rightarrow \mathrm{XTCRT}$ & 2.700 \\
\hline XTAST $\longrightarrow$ RKGE & $31.098^{a}$ & $\mathrm{XUMAL} \longrightarrow \mathrm{RKGE}$ & $30.559^{a}$ \\
\hline RKGE $\longrightarrow$ XTAST & $9.224^{\mathrm{a}}$ & RKGE $\longrightarrow$ XUMAL & $14.707^{b}$ \\
\hline XMANA $\longrightarrow$ RKGE & $11.878^{\mathrm{a}}$ & XBANK $\longrightarrow$ RKGE & $29.643^{a}$ \\
\hline RKGE $\longrightarrow$ XMANA & 1.437 & RKGE $\longrightarrow$ XBANK & $15.569^{b}$ \\
\hline $\mathrm{XMESY} \longrightarrow \mathrm{RKGE}$ & $16.064^{a}$ & $\longrightarrow$ RKGE & $15.284^{a}$ \\
\hline RKGE $\longrightarrow$ XMESY & 0.415 & RKGE $\longrightarrow$ XTEKS & 1.006 \\
\hline $\mathrm{XUHIZ} \longrightarrow \mathrm{RKGE}$ & $38.901^{a}$ & $\mathrm{XGMYO} \longrightarrow \mathrm{RKGE}$ & $38.830^{a}$ \\
\hline RKGE $\longrightarrow$ XUHIZ & 4.746 & $\mathrm{RKGE} \longrightarrow \mathrm{XGMYO}$ & 0.756 \\
\hline $\mathrm{XFINK} \longrightarrow$ RKGE & $9.789^{b}$ & $\longrightarrow$ RKGE & $14.183^{a}$ \\
\hline RKGE $\longrightarrow$ XFINK & $15.130^{\mathrm{a}}$ & RKGE $\longrightarrow$ XUTEK & 2.870 \\
\hline
\end{tabular}

${ }^{a}$ ve ${ }^{b}$ sırasıyla \%1 ve \%5 anlamlılık düzeylerini göstermektedir.

\section{Sonuç}

Finans alanında geleneksel yaklaşımda hisse senedi fiyatlamasının firmaya özgü ve makroekonomik faktörlerden etkilendiğine odaklanılmıştı. Ancak son yıllarda, hisse senedi fiyat davranışını açıklamak için psikolojik faktörler dikkate alınmaya başlanmıştır. Bu faktörlerden bir tanesi geleceğe yönelik beklentilerdir ve bu beklentiler güven endeksleri yardımıyla ölçülebilmektedir. Bu çalışmada reel kesim temsilcilerinin beklentilerini ortaya koyan Reel Kesim Güven Endeksi (RKGE) ile Borsa İstanbul sektör endeks getirileri arasındaki ilişkiler incelenmiştir. 2007:01-2016:11 dönemi için yapılan çalışmada borsa endeksleri olarak XUSIN, XGIDA, XTEKS, XKAGT, XKMYA, XTAST, XMANA, XMESY, XUHIZ, XELKT, XULAS, XTRZM, XTCRT, XUMAL, XBANK, XFINK, XGMYO ve XUTEK kullanılmıştır.

$A D F$ ve PP birim kök sonuçları \%5 anlamlılık düzeyinde RKGE'nin 1. farkında, borsa endekslerinin ise seviyesinde durağan olduğunu göstermiştir. ADF ve PP birim kök testlerine göre serilerin farklı seviyede durağan olduğu belirlenmiş olup seriler arasındaki eşbütünleşme ilişkisi Pesaran vd. (2001) tarafindan geliştirilen Sınır Testi yaklaşımı ile araştırılmıştı. Sınır testi sonuçları ise her bir borsa endeksinin ayrı ayrı RKGE ile eşbütünleşik olduğunu göstermiştir. Eşbütünleşme ilişkisinin varlığı neticesinde ARDL yöntemiyle uzun ve kısa dönem model tahmini yapılmıştır. Uzun dönemde sadece XMANA'nın uzun dönem katsayıSı ile RKGE arasında pozitif yönde ilişkili olduğu belirlenmiştir. RKGE'nin diğer endeksler üzerindeki etkisi ise anlamsız bulunmuştur. Kısa dönemde RKGE'nin her bir sektör endeksi ile ilişkili olduğu ilaveten RKGE'deki yükselişin tüm BIST sektör endekslerinin getirilerini (XULAS ve XTAST hariç) pozitif yönde etkilediği tespit edilmiştir. Bu durum RKGE'nin yatırımcılar tarafindan borsa açısından öncü bir gösterge olarak dikkate alındığını göstermektedir. Nitekim üretim, siparişler, maliyet, kapasite kullanımı gibi faktörlerde beklenen iyileşmeler şirket karlılığını olumlu yönde etkileyecek ve bu olumlu etki hisse senetlerini de arttıracaktır.

ikili seriler arasındaki nedensellik ilişkileri ise Toda-Yamamoto nedensellik testi ile araştırılmış ve elde edilen bulgular XUSIN, XKMYA, XMANA, XUHIZ, XULAS, XELKT, XTRZM, XTCRT, XUMAL, XTEKS, XGMYO ve XUTEK'ten RKGE'ne doğru bir nedensellik ilişkisinin var olduğu belirlenmiştir. Sonuç olarak, bu sektörler için hisse senedi getirilerinin reel kesimin beklentilerini yönlendirdiği söylenebilir. ilaveten RKGE'nden XGIDA'ya doğru tek yönlü, XKAGT, XTAST, XFINK, XUMAL ve XBANK ile RKGE arasında ise çift yönlü bir nedensellik 
ilişkisinin var olduğu tespit edilmiştir. Buna göre hisse senedi getirilerindeki değişimlerin reel kesim güveninin önemli bir açıklayıcısı olarak görüldüğü söylenebilir. Analiz sonuçları, reel kesim güven endeksinin bu sektör hisse senetleri için önemli bir faktör olduğunu ortaya koymuştur.

Sonuç olarak elde edilen bulgular araştrrmacılar ve uygulayıcıların, hisse senedi piyasalardaki değişimlerin belirleyicisi olarak psikolojik faktörleri dikkate alması gerektiğini göstermiştir. Illaveten hisse senedi piyasalarındaki gelişmelerin reel kesim tarafindan dikkate alındığı da görülmektedir. Ilerleyen çalışmalarda farklı endeksler ele alınarak literatüre katkı yapılabilir.

\section{Son Notlar}

1. Bu çalışmanın özeti Ulus/ararası Ekonomi, Finans ve Yönetim Konferansı'nda sunulmuştur.

2. XGIDA, XKAGT, XMESY, XUMAL, XBANK için hesaplanan Wald testi sonuçları $\% 5$ seviyesinde anlamlı bulunmuştur.

\section{Kaynaklar}

Arısoy, i. (2012). Türkiye ekonomisinde iktisadi güven endeksleri ve seçilmiş makro değişkenler arasındaki ilişkilerin VAR analizi. Maliye Dergisi, 162, 304-315.

Bolaman, Ö., \& Mandacı, P. E. (2014). Effect of investor sentiment on stock markets. Finansal Araştirmalar ve Çalışmalar Dergisi, 6(11), 51-64.

Bozdağlığlu, E.Y. U. (2007). Türkiye'nin ithalat ve ihracatının eşbütünleşme yöntemi ile analizi (1990-2007). Gazi Üniversitesi Iktisadi ve Idari Bilimler Fakültesi Dergisi 9(3), 213 - 224

Bremmer, D. (2008). Consumer confidence and stock prices. 72nd Annual Meeting of the Midwest Economics Association, Hyatt Regency, Chicago, Illinois.

Brown, G. W., \& Cliff, M. T. (2004). Investor sentiment and the near-term stock market. Journal of Empirical Finance, 11(4), 1-27.

Charoenrook, A. (2005). Does sentiment matter?. Working Paper No: 3301937, Vanderbilt University, https://apps.olin.wustl.edu/workingpapers/pdf/2008-12-003.pdf, (03.11.2016).

Chen, S. (2011). Lack of consumer confidence and stock returns. Journal of Empirical Finance, 18, 225-236.

Christ, K. P., \& Bremmer, D. S. (2003). The relationship between consumer sentiment and stock prices, 78th Annual Conference of the Western Economics Association International, Denver-ABD.

Çetintaş, H., \& Bektaş, Ç. (2008). Türkiye'de turizm ve ekonomik büyüme arasındaki kısa ve uzun dönemli ilişkiler. Anatolia: Turizm Araştırmaları Dergisi, 19(1), 37-44.

Dickey, D. A. \& Fuller, W. A. (1981). Likelihood ratio statistics for autoregressive time series with a unit root. Econometrica, 49(4), 1057-1072.

Fisher, K. L., \& Statman, Meir. (2003). Consumer confidence and stock returns. The Journal of Portfolio Management, 30(1), 115-127.

Ghosh, A., \& Clayton, R. (2004). The relationship between the consumer sentiment index and the stock market. 2004 FMA European Conference, 2-4 Haziran, Zürih-İsviçre.

Görmüş, Ş. \& Güneş, S. (2010). Consumer confidence, stock prices and exchange rates: The case of Turkey. Applied Econometrics and International Development, 10(2), 103-114.

Jansen, W. J., \& Nahuis, N. J. (2003). The stock market and consumer confidence: European evidence. Economics Letters, 79(1), 89-98.

Kale, S., \& Akkaya, M. (2016). The relation between confidence climate and stock returns: The case of Turkey. Procedia Economics and Finance, 38, 150-162.

Kandır, S. Y. (2006). Tüketici güveni ve hisse senedi getirileri iliş̧kisi: iMKB Mali sektör şirketleri üzerinde bir uygulama. Çukurova Üniversitesi Sosyal Bilimler Enstitüsü Dergisi, 15(2), 217-230.

Kızılgöl, Ö.A. (2011). Mevsimsel eşbütünleşme testi: Türkiye'nin makroekonomik verileriyle bir uygulama. Atatürk Üniversitesi iktisadi ve Idari Bilimler Dergisi, 25(2), 13-25. 
Korkmaz, T., \& Çevik, E. İ. (2007). Güven endeksi ve yattrımcıların sezgileri: Türkiye Örneği, 11. Ulusal Finans Sempozyumu Zonguldak Kara Elmas Üniversitesi, 17-20 Ekim, 389-409.

Korkmaz, T., \& Çevik, E. İ. (2009). Reel Kesim Güven Endeksi ile IMKB 100 Endeksi arasındaki dinamik nedensellik ilişkisi. İstanbul Üniversitesi Işletme Fakültesi Dergisi, 38(1), 24-37.

Lin, C., Ho, C., \& Fang, V. (2005). Australian consumer sentiment and sector return, http://citeseerx.ist.psu.edu/viewdoc/download?doi=10.1.1.584.402\&rep=rep1\&type=pdf, 12.12.2016

Marczak, M., \& Beissinger, T. (2016). Bidirectional relationship between investor sentiment and excess returns: New evidence from the Wavelet perspective. Applied Economics Letters, 23(18), 1305-1311.

$\mathrm{Ni}$, Z., Wang, D., \& Xue, W. (2015). Investor sentiment and its nonlinear effect on stock returns-new evidence from the Chinese stock market based on panel quantile regression model, Economic Modelling, 50, 266-274.

Olgaç, S., \& Temizel, F. (2008). Yatırımcı duyarlılığı hisse senedi getirileri ilişkisi: Türkiye örneği. TiSK Akademi, 3(6), 224239.

Otoo, M. W. (1999). Consumer sentiment and the stock market. Board of Governors of the Federal Reserve System, 1 20.

Pesaran, M. H., Shin, Y., \& Smith, R. J. (2001). Bounds testing approaches to the analysis of level relationships. Journal of Applied Econometrics, 16, 289-326.

Phillips, P. C., \& Perron, P. (1988). Testing for a unit root in time series regression. Biometrika, 75(2), 335-346.

Qiu, L. \& Welch, I. (2004). Investment sentiment measures. NBER Working Paper, No: W10794.

Schmeling, M. (2009). Investor sentiment and stock returns: Some international evidence. Journal of Empirical Finance, 16(3), 394-408.

TCMB, http://-www.tcmb.gov.tr-/wps-/wcm/connect/-tcmb+tr/tcmb+tr/-main+menu/-istatistikler/-egilim+anketleri/iktisadi+yonelim+anketi, 21.12.2016.

Toda, H. Y., \& Yamamoto, T. (1995). Statistical inference in vector autoregressions with possbly integrated process. Journal of Econometrics, 66, 225-250.

Topuz, Y. V. (2011). Tüketici güveni ve hisse senedi fiyatları arasındaki nedensellik ilişkisi: Türkiye örneği. Ekonomik ve Sosyal Araştirmalar Dergisi, 7(1), 53-65.

Türe, H., \& Akdi, Y. (2005). Mevsimsel kointegrasyon: Türkiye verilerine bir uygulama. 7. Ulusal Ekonometri ve İstatistik Sempozyumu, Düzenleyen: İstanbul Üniversitesi, 26-27 Mayıs.

Ulusoy, A., Yamak, R., \& Şahingöz, B. (2016). Faiz dışı dengenin ekonomik büyüme ve işsizlik üzerine etkisi. Ekonomi Bilimleri Dergisi, 8(1), 1-33. 